\title{
The Challenge of Soil Erosion: Where Do We Now Stand?
}

\author{
John Boardman* \\ Environmental Change Institute, University of Oxford, UK; Department of Geography, University of the Free State, South Africa
}

Submission: October 14, 2018; Published: October 24, 2018

*Corresponding author: John Boardman, Department of Geography, University of the Free State, South Africa, Environmental Change Institute, University of Oxford, UK, Email: John.Boardman@eci.ox.ac.uk

\section{Abstract}

Issues around soil erosion continue to be widely debated in major journals and books. In the last 30 years there have been considerable advances in the understanding of off-site impacts of muddy flooding and fresh water pollution, and in flood protection. However, progress in erosion prediction has been disappointing especially in the continued reliance on out-dated and unreliable models. Alternative approaches using field-scale assessments are available and need to be more widely used.

Keywords: Soil Erosion: Off-Site Impacts; Erosion Models; Field-Scale Assessment; Soil Conservation

\section{Opinion}

This short review addresses some of the main issues to emerge in the sphere of soil erosion studies in the last c.30 years. During this time, the global output of papers and reports on soil erosion is impressive. Major journals devote considerable space to the topic: Catena, Earth-Science Reviews, Earth Surface Processes and Landforms, Geomorphology, Journal of Soil Conservation, Journal of Soils and Sediments, Land Degradation and Development, Soil and Tillage Research, Soil Use and Management. Various important reviews have appeared e.g [1] on rill and interrill contributions; [2] on gullies; [3] on rill data from plots and [4] on climate change and erosion. Edited books have attempted to pull together disparate studies e.g. [510] and Morgan's text book continues to be widely used [11]. Trimble's review of erosion in the Upper Mississippi hill country is an outstanding historical survey of periods of excessive erosion and latterly the success of conservation tillage [12]. Soil erosion is not a self-contained, easily-bounded subject. Thus, highly relevant studies appear in sub-disciplinary areas such as hydrology (sediment yields), lacustrine, arid and grazing studies, agronomic and agricultural areas. Erosion is not simply driven by physical factors [13], and therefore cognate disciplines of rural sociology, land use studies and rural economics play an important part: this is especially the case when considering the role of farmers in soil conservation. The recent exhibition of the photographs of Dorothea Lange in London and Paris, reminds us of the human costs of erosion [14].

\section{Successes and Failures}

In this time period there have been significant successes, areas where the science or practice has advanced. On the other hand, particularly in the area of erosion prediction, progress has been disappointing. The distinction between on-farm and offfarm impacts of erosion is clear. In western Europe, the on-farm threat of thinning soils impacting on crop yields, is now seen as a medium term, non-urgent threat [15] whereas, off-site damage to properties by muddy flooding is reported in many countries and associated costs are high $[16,17]$. The latter threat spans the boundary between soil conservation and flood protection and often requires specific protection measures to address off-farm, down-valley impacts.

A successful scheme in Flanders, Belgium, addresses these issues including the need to properly finance local floodprotection measures in towns and on adjacent farm land [18]. Growing awareness of the damage to freshwater systems by excess fine sediment, phosphorus, nitrates and metaldehyde, often from farmers' fields, has been driven by the European Union's Water Framework Directive [19]. This awareness drives the England-based Demonstration Test Catchment approach to tackling freshwater pollution e.g [20]. However, the globalscale threat to soils on the farm is far less clear because of the unreliability of the data. For the last thirty years, assessments of the scale and extent of global land degradation (including erosion) have tended to rely on GLASOD data [21]. This is qualitative and subjective and provides only a very generalised assessment.

In the last thirty years little progress has been made in erosion prediction using models. The choice is still between USLE-based empirical models and process-based models such as WEPP and EUROSEM. A panoply of other models falls into these two categories. The USLE and its derivatives are widely used because of their simplicity but extrapolation from databases 
developed on experimental plots $(22 \times 2 \mathrm{~m})$, to the field scale, patently does not work. It therefore remains unvalidated and promulgates misleading results $[22,23,3]$. On the other hand, process-based models have proved to be too data-hungry for widespread use. The EU has chosen to invest resources in a USLE approach. The sophisticated use of GIS and remote sensing does not disguise the fact that the resultant maps are unvalidated and in many cases plainly wrong $[24,25]$. The USLE over emphasises gradient and rainfall and under emphasises vegetative cover. Bandwagons in science are difficult to derail as evidenced by the 'success' of ${ }^{137} \mathrm{Cs}$ as an erosion assessment tool despite the evidence for caution [26]. In the UK, a relatively simple approach to erosion assessment has proved valuable. Field mapping of selected representative areas provides data on soils, the extent, frequency and risk of each crop to erosion $[27,28]$. Around this basic knowledge, detailed studies of particular risks such as those of extreme events [29], low-magnitude, high-frequency events [30], and pollution risks associated with runoff [31], have been assembled.

Models have also been used to support the idea of very high rates of erosion. Observed spatial and temporal variabilities of erosion across farmed landscapes suggest that average rates of $>20 \mathrm{t} \mathrm{ha}^{-1} \mathrm{yr}^{-1}$ are likely to be extremely rare. USLE predictions of $>40 \mathrm{t} \mathrm{ha}^{-1} \mathrm{yr}^{-1}$ are unlikely [32], and at the very least require supporting empirical evidence. Extreme rates such as $202 \mathrm{~m}^{3}$ $\mathrm{ha}^{-1} \mathrm{yr}^{-1}$ on a UK field, when seen in the context of the spatial variability of erosion across the landscape [29], and long-term temporal variability, can be seen as what they are: extreme, nontypical events - but often with considerable off-site impacts [33].

While results from models have been generally disappointing, field-scale monitoring of erosion based on the first national survey, has produced data that compares well with other assessments, is cheap and for which the errors are known [34]. Finally, real progress has been made in understanding the connectivity or dis-connectivity of erosional processes [35], This is important as it addresses the management issue at the catchment scale rather than that of the individual field or watercourse. Progress is also evident in the adoption of conservation tillage especially in north and south America. This is not without its problems such as lower yields and polluted runoff but is likely good news for erosion control. In this, and other approaches, we still seek solutions to the dilemma of producing more food and limiting erosion and pollution, or what has recently been characterised as the need for 'smart intensification' [36].

\section{Acknowledgements}

I thank Professor Ian Foster and Dr Bob Evans for comments on the opinion piece.

\section{References}

1. Govers G, Poesen J (1988) Assessment of the interrill and rill contributions to a total soil loss from an upland field plot. Geomorphology 1(4): 343-354.

2. Poesen J, Nachtergaele J, Verstraeten G, Valentin C (2003) Gully erosion and environmental change: importance and research needs. Catena 50(2-4): 91-13.

3. Cerdan O, Govers G, Le Bissonnais Y, Van Oost K, Poesen J (2010) Rates and spatial variations of soil erosion in Europe: a study based on erosion plot data. Geomorphology 122(1-2): 167-177.

4. Li Z, Fang H (2016) Impacts of climate change on water erosion: a review. Earth-Science Reviews 163: 94-117.

5. Boardman J, Foster IDL, Dearing JA (1990) (eds) Soil Erosion on Agricultural Land. Chichester: Wiley, pp. 687.

6. Pimental D (1993) (ed) World Soil Erosion and Conservation. Cambridge: Cambridge University Press, 5(1): 60-60.

7. Wicherek S (ed) (1993) Farm Land Erosion: In Temperate Plains Environment and Hills, Amsterdam: Elsevier, pp. 587.

8. Penning de Vries FWT, Agus F, Kerr J (1998) (eds) Soil Erosion at Multiple Scales. Wallingford, UK: CAB International 12(1): 90-91.

9. Li Y, Poesen J, Valentin C (2004) (eds) Gully Erosion under Global Change. Chengdu, China: Sichuan Science and Technology Press, pp. 354 .

10. Boardman J, Poesen J, Evans R (2003) Socio-economic factors in soil erosion and conservation. Environmental Science \& Policy 6(1): 1-6.

11. Morgan RPC (2005) Soil Erosion and Conservation 3rd Edition, Oxford: Blackwell, 56(5): 686-686.

12. Trimble SW (2013) Historical Agriculture and Soil Erosion in the Upper Mississippi Valley Hill Country. Boca Raton, Florida CRC Press, Taylor and Francis Group 27(4): 1307-1307.

13. Boardman J, Poesen J, Evans R (2003) Socio-economic factors in soil erosion and conservation Environmental Science \& Policy 6(1): 1-6.

14. Pardo A, Golbach J (2018) (eds) Dorothea Lange: Politics of Seeing. Munich: Prestel, pp. 288.

15. Bakker MM, Govers G, Rounsevell MDA (2004) The crop-productivityerosion relationship: an analysis based on experimental work. Catena 57(1): 55-76.

16. Boardman J, Verstraeten G, Bielders C (2006) Muddy floods. In Boardman J, Poesen J (eds) Soil Erosion in Europe, Wiley, Chichester, pp. 743-755.

17. Evrard O, Bielders C, Vandaele K, van Wesemael B (2007) Spatial and temporal variation of muddy floods in central Belgium, off-site impacts and potential control measures. Catena 70(3): 443-454.

18. Boardman J, Vandaele K (2015) Effect of the spatial organisation of land use on muddy flooding from cultivated catchments and recommendations for the adoption of control measures. Earth Surface Processes and Landforms 41(3): 336-343.

19. European Parliament (2000) Establishing a framework for community action in the field of water policy. Directive EC/2000/60, EU, Brussels.

20. Biddulph M, Collins AL, Foster IDL, Holmes N (2017) The scale problem in tackling diffuse water pollution from agriculture: insights from the Avon Demonstration Test Catchment programme in England. Rivers Research and Applications 33: 1527-1538.

21. Oldeman LR, Hakkeling RTA, Sombroek WG (1991) World map of the status of human-induced soil degradation: an explanatory note. Wageningen: International Soil Reference and Information Centre; Nairobi: United Nations Environment Programme.

22. Boardman J (1998) An average soil erosion rate for Europe: myth or reality? Journal Soil and Water Conservation 53(1): 46-50.

23. Evans R, Brazier R (2005) Evaluation of modelled spatially distributed predictions of soil erosion by water versus field-based assessments. Environmental Science \& Policy 8(5): 493-501. 
24. Evans R, Boardman J (2016a) The new assessment of soil loss by water erosion in Europe. Panagos P. et al. 2015 Environmental Science \& Policy 54, 438-447 - A response. Environmental Science \& Policy 58: 11-15.

25. Evans R, Boardman J (2016b) A reply to Panagos et al., 2016 (Environmental Science \& Policy 59, 53-57). Environmental Science \& Policy 60: 63-68.

26. Parsons AJ, Foster IDL (2011) What can we learn about soil erosion from the use of 137Cs? Earth Science Reviews 108: 101-113.

27. Evans R (1990) Soils at risk of accelerated erosion in England and Wales. Soil Use and Management 6: 125-131.

28. Evans R (2013) Assessment and monitoring of accelerated water erosion of cultivated land - when will reality be acknowledged? Soil Use and Management 29 (1): 105-111.

29. Boardman J (1988) Severe erosion on agricultural land in East Sussex, UK, October 1987. Soil Technology 1(4): 333-348.

30. Evans R (2017) Factors controlling soil erosion and runoff and their impacts in the upper Wissey catchment, Norfolk, England: a ten year monitoring programme. Earth Surface Processes and Landforms 42(14): 2266-2279.
31. Harrod TR (1994) Runoff, soil erosion and pesticide pollution in Cornwall. In RJ Rickson (ed) Conserving Soil Resources: European Perspectives, 105115, Wallingford, UK: CAB International.

32. Lalitha M, Dharumarajan S, Niranjana KV, Srinivas S, Naidu LGK, Sarkar D (2016) Need for site specific land resource database for integrated watershed management. Indian Journal of Soil Conservation 44(2): 168-176.

33. Evans R, Collins AL, Zhang Y, Foster IDL, Boardman J (2017) A comparison of conventional and $137 \mathrm{Cs}$-based estimates of soil erosion rates on arable and grassland across lowland England and Wales. Earth-Science Reviews 173: 49-64.

34. Evans R, Collins AL, Foster IDL, Rickson RJ, Anthony SG (2016) Extent, frequency and rate of water erosion of arable land in Britain benefits and challenges for modelling. Soil Use and Management 32: 149-161.

35. Fryirs KA, Brierley GA, Preston NJ, Kasai M (2007) Buffers, barriers and blankets: the (dis)connectivity of catchment-scale sediment cascades. Catena 70(1): 49-67.

36. Govers G, Merckx R, van Wesemael B, Van Oost K (2017) Soil conservation in the 21st century: why we need smart agricultural intensification. Soil 3: 45-59.

This work is licensed under Creative Commons Attribution 4.0 License DOI: 10.19080/IJESNR.2018.15.555904 